\title{
Analysis of understanding level of government welfare schemes (Among beedi workers of unorganized sector)
}

Fatima Qasim, (Author) Ph.D. Scholar- JSBS\&C, SHUATS-Prayagraj.

Dr. Sneh P. Daniel, (Co-Author), Assistant Professor, JSBS\&C, SHUATS-Prayagraj

Electronic version

URL: http://www.researchambition.com

DOI: https://doi.org/10.53724/ambition/v6n1.05

ISSN: 2456-0146

Vol. 6, Issue-I, August 2021

Page No. 14-21

Publisher

Welfare Universe

email: publish2017@gmail.com

CResearch Ambition: An International Multidisciplinary e-Journal 2021. This Open Access article is published under a Creative Commons Attribution Non-Commercial 4.0 International License https://creativecommons.org/licenses/by-nc/4.0/, which permits non-commercial reuse, distribution, and reproduction in any medium, provided the original work is properly cited. For citation use the DOI. For commercial re-use, please contact editor email:- publish2017@ gmail.com By accessing the work you hereby accept the Terms. Non-commercial uses of the work are permitted without any further permission from Research Ambition: An International Multidisciplinary eJournal provided the work is properly attributed. 


\section{ANALYSIS OF UNDERSTANDING LEVEL OF GOVERNMENT WELFARE SCHEMES (AMONG BEEDI WORKERS OF UNORGANIZED SECTOR)}

\section{Abstract}

*Fatima Qasim

Beedi fabricating is perhaps the biggest business in India utilizing a huge number of laborers, lion's share of them being ladies and kids. It falls under the class of sloppy area and thusly draws in numerous shades of malice like helpless working conditions, absence of execution of government rules and guidelines, work of kid work, low wages, sporadic business etc. Government has arranged and carried out numerous government assistance plans for these laborers that incorporate health advantages, protection, lodging, schooling, diversion, maternity and so on for their upliftment. Nonetheless, the degree of attention to these plans is very low and execution is negligible because of low degree of training among these specialists. The current investigation dives into the segment profile of these specialists alongside their degree of mindfulness in regards to government assistance plans. The information was gathered from Prayagraj in Uttar Pradesh from 347 respondents. The information was investigated utilizing proportions of focal inclination, chi square test and Kruskal-Wallis test. The definite investigation of information uncovered that these specialists are having low pay and instruction level, generally utilizing ladies from the moderately aged gatherings. These laborers are tolerably mindful about the plans and lower age-bunch laborers are more mindful about government assistance program than their senior partners. The investigation proposes approaches to ad lib the everyday environments of these laborers and plans to make mindfulness about the government assistance program of the public authority.

Keywords: Beedi workers, unorganized sector, welfare schemes.

\section{Introduction:}

A beedi can be characterized as an Indian cigarette which involves tobacco chip which is enclosed by a tendu leaf and got with cotton string. In spite of the fact that it is a less expensive option in contrast to cigarette and exceptionally well known among the country and non-well-to-do individuals in India, it bears high wellbeing hazards not exclusively to the shoppers yet in addition to beedi producers (Kumar and Bharti, 2010). ${ }^{1}$

Beedi producing in India returns to mid-20th century and is considered agro-backwoods based industry; it is work serious and profoundly chaotic area. The business utilizes biggest number of workforces in India which is trailed by horticulture area, handloom industry and development industry. Apparently, the piece of the pie of beedi industry in India is $85 \%$ of the multitude of smoking items, and is devoured by 7.7 percent of grown-ups in India (Arora et al., 2020). ${ }^{2}$

The beedi producing industry has moved to disorderly area from being a piece of coordinated area before, because of exacting government rules, guidelines and approaches on the coordinated area and the expense progression in the chaotic area. By and by in India, beedi fabricating industry can be arranged as: a) 'enlisted organizations' that produce in excess of 2 million marked beedis per annum, pay extract obligation and observe work laws; b) 'unregistered organizations' are excluded from charge installments, as they make under 2 million beedis in a year. Also, with the execution of new GST (Goods and Services Tax) in 2019, organizations with a turnover of Rs. 4 million have been excluded from the duty from the monetary year 2019-2020 onwards. Thusly, the presentation of this new assessment change has absolved, almost $98 \%$ of the beedi makers.

Beedi moving as generally called is a significant industry in the vast majority of the states in India including Madhya Pradesh, Maharashtra, Gujarat, Tamil Nadu, Andhra Pradesh, West Bengal, Orissa, Uttar Pradesh, Rajasthan, Bihar, Kerala and Karnataka. Nonetheless, the development and development of tobacco which is the significant element of beedi 
producing, is significantly done in Gujarat, Karnataka, and Maharashtra, what's more, in certain pieces of Orissa and Andhra Pradesh. While the 'tendu' leaves which is utilized to wrap beedi is significantly developed in Madhya Pradesh, Orissa, Maharashtra, Andhra Pradesh and Bihar.

As per government information the assessed workforce associated with beedi moving is over 4-5 million significantly captivating ladies' laborers telecommuting; these evaluations as indicated by profession associations are near 7 million. Unnecessary to specify, these laborers fall underneath the destitution line, are come up short on, untalented, have a place with in reverse regions and have no elective type of revenue.

Since beedi laborers fall under the chaotic area, they are viewed as the weakest part of the general public, subsequently are dependent upon misuse in work environment. Accordingly, there is a requirement for significant changes in this area. The public authority has sanctioned different laws relating to their government assistance and prosperity which whenever executed successfully can prompt their upliftment. The significant issues looked by these beedi laborers in their working environment may incorporate a) lodging/cover issues; b) come up short on; c) dismissal of beedi parts by workers for hire; d) unhygienic working conditions; e) ailments like disease, T.B, eye issues because of inward breath of tobacco; f) absence of clinical offices extraordinarily to lady's workforce; g) absence of instruction, and so on.

\section{Welfare Schemes}

Keeping the above in view, the major Welfare Schemes launched by government are as follows:

Clinical and Health Plans: The beedi laborers the nation over can profit health advantages from 8 government medical clinics and 236 dispensaries. Moreover, they can likewise profit other clinical help with the type of: a) 'labor help' to ladies beedi specialist who has worked for over a half year in the beedi fabricating adding up to Rs. 1000 for initial 2 kids; b) 'family government assistance' as financial remittance to male specialists for going through cleansing interaction to advance family arranging; c) 'guide on glasses buy' is given to laborers as Rs. 300 for the acquisition of eye exam.

Getting consent prior to taking therapy: The beedi laborers or their wards are needed to look for authorization as endorsed design from the Welfare Commissioner to get therapy from a perceived malignant growth emergency clinic. The public authority has set up a solitary window to facilitate the interaction and it requires as long as 15 days to get consent.

Repayment of consumption on clinical therapy: The sum borne by the beedi specialist during his or his reliant therapy for an illness at a malignant growth emergency clinic perceived by the public authority are repay on genuine use on treatment, meds and diet charges.

Resource Allowance: Such remittance is given to the laborers on the off chance that he/she is the just acquiring part and has no other kind of revenue during the time of treatment. The resource remittance adds up to Rs.600-750 every month and will be paid to the specialist going through therapy for disease.

Rail line Fare: The public authority gives back and forth inferior passage for transport or railroad to the patient alongside a specialist from his occupant city to the emergency clinic.

Day by day Allowance: A Day-by-day stipend of Rs. 50 every day to the patient and his specialist both is paid for ahead and bring ventures back.

Accommodation of Claims: For repayment of consumption for therapy of disease, an application in the endorsed design is to be presented by the specialist to the Welfare Commissioner through his manager.

Schooling Facility: Education offices are given to the offspring of laborers beedi laborers by giving grant. The public authority gives monetary help both of the guardians of the understudies ought to be beedi specialist with in any event a half year in assistance and their complete month to month Income from all sources ought not to surpass Rs. 10,000.

Lodging Schemes: In the year 2015, the public authority had built 16,552 houses for beedi and non-coal mineshaft laborers; and as indicated by government's aspiring 'Lodging for All' project 2 crore houses in five stages till 2022 are under the 
pipeline. Likewise, Rs. 1 lakh will be dispensed to laborers under 'ghetto recovery program' and Central help adding up to Rs. 1.5 lakh will be given to underneath the neediness line laborers.

Recreational Schemes: Beedi workers can avail the facility of recreational units of TV amounting up to Rs 10,000 subject to not more than two T.V. sets per region during a financial year.

\section{Status of Beedi Workers}

As referenced before, the beedi business goes under chaotic area. Beedi moving occurred in the production line area toward the start of the 20th century; be that as it may, for as long as couple of many years it has moved its base from industrial facilities to limited scope set-ups generally locally established, utilizing families as laborers across sex and age. By and by, the major beedi producers comprise just $10 \%$ of whole beedi fabricating, since lion's share of these makers contract out crafted by moving beedis to project workers who further sub-provisional labor to people at homes on a piece-rate wage framework. Thusly, it gets hard to fabricate boss representative relationship as characterized by work laws in beedi producing industry.

Since the beedi making for the most part happens at home and is to a great extent dependent on legally binding piece rate framework, it turns into an underlying driver of bleak states of laborers occupied with this exchange. There is allowance in compensation because of unacceptable work, installment isn't on schedule, unpredictable business, abuse by mediators, work of kid work, wellbeing perils, helpless everyday environments, absence of instruction are a portion of the normal stories of these beedi laborers (Ansari and Raj, 2015). ${ }^{3}$ Purportedly, these beedi laborers are abused in different structures, for example, they are given less amount of material to per thousand beedis required, dismissal of last beedis subsequently cut in installments, mindfulness about work laws is insignificant and dominant part of these specialists are without satisfactory living space and essential conveniences (Ansari and Raj, 2020). ${ }^{4}$

Moreover, the degree of mindfulness about the government assistance conspire in India among beedi laborers is baffling in nature. As per an investigation conveyed by Sudina and Francis $(2015)^{5}$ the beedi laborers were discovered to know about health advantages identified with eye glasses (23.5 percent), heart issues (23.5 percent), kidney issues ( $9 \%$ ), tuberculosis therapy (5\%) and disease treatment (17.5 percent). The investigation additionally uncovered a relationship expressing those instructive advantages for grants increment with the expansion in instructive degree of laborers.

Mindfulness on instructive advantages for grants accessible increments as the norm of schooling increments among these laborers. As to, benefits, 80.5 percent knew about and 7 percent about family arranging plan. Among the beedi laborers, just 14.5 percent thought about house building stipend, 34.5 percent thought about remittance for common passing and 1.5 percent about recompense for incidental demise (Sudina and Lakra 2015). ${ }^{6}$

Notwithstanding the dispatch of a few governments' assistance plans by government, allegedly, the beedi laborers don't visit the beedi emergency clinics and dispensaries consistently as they don't know about these plans (Sundar Moorthy et al., 2011). ${ }^{7}$ The situation of these laborers is ascribed to their instructive level. According to an examination, 37 percent of the beedi laborers are ignorant and greater part of them $(91 \%)$ have either secondary school capabilities or secondary school nonconformists. Low instructive level is one reason for the laborers to utilize in beedi moving work (Pankaj and Dolas, 2010). ${ }^{8}$

Since this industry utilizes enormous number of ladies, there have been issues related with the government assistance and prosperity of ladies on the loose. As indicated by an investigation conveyed by Devi and Thayammal (2017) ${ }^{9}$ the majority of the ladies beedi laborers had communicated a moderate degree of mindfulness on government plans for beedi laborers. Likewise, their examination uncovers that the attention to ladies beedi laborers on government plans contrasted by their age. The current paper manages the segment profile of these laborers and their mindfulness about the different government assistance benefits planned by the public authority with an uncommon reference to laborers amassed in Prayagraj in Uttar Pradesh. 


\section{Research Methodology}

The research design is built to study the objective to find out the awareness of various welfare programme provided by the government to the beedi workers.

Coverage: The current investigation manages the beedi making units packed in the spaces around Prayagraj in Uttar Pradesh. The significant regions managing moving of beedis in Prayagraj are Roshan Bagh, Ranimandi, Atala, Darashahajmal, Mahewa, Naini. Moving beedis at home and in limited scope set up structures one of the significant wellsprings of work in provincial and spaces of Prayagraj.

As referred to previously, this region which is for the most part messy uses gigantic number of women and children, provoking defenseless ordinary conditions due to insufficient execution of work laws. Likewise, these workers are not considered as enduring ones and hereafter denied of clinical workplaces and various benefits. The wages are not as per the Minimum Wages Act, provoking shortfall of fundamental accommodations like food, water and safe house for these trained professionals. These experts are moreover socially abused and denied the security, balance and respect with no affirmation of future. The current assessment deals with the knowledge of government help plans of government being planned for the upliftment of the workers busy with messy region.

Sampling design: The examination covers the beedi laborers utilized by numerous beedi producers situated in Prayagraj and Kaushambi Districts, Uttar Pradesh under the technique for comfort irregular testing strategy covering complete 270 families. An example size of 450 was picked through accommodation testing technique.

Data Collection: The information was gathered through optional and essential sources to comprehend the idea of social government assistance plans. Auxiliary information was gathered through books, law diaries, and case laws from government sites, rules, complete manual and papers.

In the current examination essential information was gathered through polls. To legitimize the reactions from the examples, segment factors have been chosen covering diverse age gatherings, sex, long periods of work insight, representative numbers, method of installment and instructive level and so on Likewise, the poll traces the government assistance programs accessible to the beedi laborers relating to health advantages, bunch protection, lodging, instruction and amusement, overhauled incorporated lodging plans, maternity benefits, schooling office, working conditions and crèche office.

The scale used for get-together data was 'Five point-Likert Scale' going from 1 for 'unequivocally contradict' 5 for 'determinedly agree'. Out of 450 responses passed on complete 347 responses got important for extra assessments that check to a sizable number. Data Analysis: The information was inspected; sorted, classified and coded to address the examination targets and the exploration questions. It was then altered and counted in recurrence table. The qualities comparing to frequencies were changed over into rates to work with investigation. The examination utilized mean and standard deviations got from the different reactions to decipher the outcomes. This was worked with by the MS Excel. The factual devices utilized for the examination were elucidating investigation, chi square test, Kruskal-Wallis test and ordinal relapse investigation.

In order to understand the study objective, the following hypothesis is drawn.

Null Hypothesis (H0): The beedi workers are not aware of various benefits under the welfare schemes.

Alternate Hypothesis (H1): The beedi workers are aware of various benefits under the welfare schemes

This study aims to understand the level of awareness of the welfare schemes towards the government schemes. This paper attempts to highlight the plight of the beedi workers and help the NGOS and other academics to work for their upliftment in the society.

This study aims to understand the level of awareness of the welfare schemes towards the government schemes. This paper attempts to highlight the plight of the beedi workers and help the NGOS and other academics to work for their upliftment in the society. 


\section{Demographic Profile of Beedi Workers}

Let us understand the demographic profile of the beedi workers engaged in rolling beedis in Prayagraj.

Gender: It is seen that out of 349 respondents 124 were guys and rest 224 were ladies. As referenced before, a more prominent number of ladies labor forces are utilized in the sloppy area. The predicament of these specialists is obvious from the way that ladies of the family are utilized in procuring bread for the family.

Age: It was found in the examination that the most noteworthy number of laborers was discovered to be in the age gathering of 53 or more (22.48 percent) while the least were discovered to be in the age-gathering of 37-44. (11.24 percent). Rest of the workers were distributed as less than 20(14.70 percent), $21-28$ (20.46 percent), 29-36 (19.31 percent) and 45-52 (11.82). This indicates that the workforce is aging as they have been employed in organised sector for many decades.

Education: Needless to mention, education is one of the least priorities of the beedi workers' family. As expected, highest number of workers were found to be illiterate (32.28 percent) followed by metric pass ( 27.09 percent), followed by higher secondary (21.90 percent) and primary schooling (18.73 percent).

Income: As called attention to before, the beedi laborers are occupied with chaotic area with least pay and numerous mouths to take care of. As borne out from information, the yearly pay 26\% laborers was between 50000-74000 while just $8 \%$ specialists procure more than 100,000 in a year. Rest 9\% were acquiring in the scope of 5000-24000, 25 percent in the scope of 25000-49000 and 21 percent in the scope of 75000-99000. Obviously pay of these laborers isn't in understanding to the most recent standards.

\section{Awareness of Welfare Schemes in Beedi workers}

To test the consciousness of the beedi laborers about the different advantages under the government assistance plans 96 inquiries were posed under 16 heads and these 16 heads were additionally viewed as the variable that chooses the course of this exploration. Since the reactions gathered were in the ordinal structure to make it ceaseless the scientist determined the normal (mean) of every factor. Furthermore, these were additionally utilized for the investigation the degree of familiarity with the respondents on government plans identified with the beedi laborers were grouped into three classes, to be specific undeniable level, medium-level and low-level for examination reason.

Table-1: Scale for Level of Awareness of Welfare Schemes

\begin{tabular}{|c|c|c|c|c|c|c|}
\hline \multirow[t]{2}{*}{ S. No: } & \multirow[b]{2}{*}{ Variables } & \multicolumn{2}{|c|}{ Statistics } & \multicolumn{3}{|c|}{ Scale for level of Awareness } \\
\hline & & $\begin{array}{c}\text { Mean } \\
\text { ) }\end{array}$ & SD & $\begin{array}{l}\text { Low } \\
\text { Level }\end{array}$ & $\begin{array}{c}\text { Moderate } \\
\text { Level }\end{array}$ & $\begin{array}{l}\text { High } \\
\text { Level }\end{array}$ \\
\hline 1 & Medical & 2.89 & 1.36 & $<1.52$ & $1.5-4.24$ & $4.24<$ \\
\hline 2 & Group insurance & 2.90 & 1.29 & $<1.62$ & $1.62-4.2$ & $4.20<$ \\
\hline 3 & Housing & 2.83 & 1.05 & $<1.77$ & $1.70-3.87$ & $3.87<$ \\
\hline 4 & Recreation & 2.88 & 1.25 & $<1.64$ & $1.64-4.14$ & $4.14<$ \\
\hline 5 & Maternity benefit & 2.95 & 1.34 & $<1.60$ & $1.60-4.28$ & $4.28<$ \\
\hline 6 & Education facility & 2.93 & 1.27 & $<1.66$ & $1.66-4.20$ & $4.20<$ \\
\hline 7 & Working conditions & 2.96 & 1.37 & $<1.59$ & $1.59-4.33$ & $4.33<$ \\
\hline 8 & Crèche facility & 2.77 & 1.25 & $<1.52$ & $1.52-4.02$ & $4.02<$ \\
\hline
\end{tabular}

While the score value greater than (+ SD) was classified as high-level awareness and the score value less than ( - SD) was classified as low-level awareness respectively and the score values between $(+\mathrm{SD})$ and $(-\mathrm{SD})$ have been classified as medium level awareness. Here to find the arithmetic means and standard deviation (SD) of the score values of 347 respondents were calculated shows the mean, standard deviation and scale to gauge the degree of mindfulness for every factor i.e., the government assistance plans accessible to the beedi laborers. The current examination further explores the degree of mindfulness regarding this table, under different heads of plans which structure the factors of our investigation, to 
be specific, clinical strategies, protection plans, lodging, training, entertainment, maternity, working conditions, and crèche office.

It is plainly borne out from the Table 2 that there is by all account's moderate mindfulness about numerous government assistance plans among the beedi laborers of Prayagraj.

Table 2: Level of awareness of Welfare schemes

\begin{tabular}{|l|l|l|l|l|l||}
\hline \multirow{2}{*}{ S.No: } & \multirow{2}{*}{ Welfare Schemes } & $\begin{array}{c}\text { Low } \\
\text { Level }\end{array}$ & $\begin{array}{c}\text { Moderate } \\
\text { Level }\end{array}$ & $\begin{array}{c}\text { High } \\
\text { Level }\end{array}$ & Total \\
\hline \hline 1 & Medical & $0.58 \%$ & $99.14 \%$ & $0.29 \%$ & $100 \%$ \\
\hline \hline 2 & Group insurance & $1.73 \%$ & $93.37 \%$ & $4.90 \%$ & $100 \%$ \\
\hline \hline 3 & Housing & $16.71 \%$ & $62.82 \%$ & $20.46 \%$ & $100 \%$ \\
\hline 4 & Recreation & $5.48 \%$ & $85.88 \%$ & $8.65 \%$ & $100 \%$ \\
\hline \hline 5 & Maternity benefit & $0.00 \%$ & $99.42 \%$ & $0.58 \%$ & $100 \%$ \\
\hline 6 & Education facility & $2.31 \%$ & $95.68 \%$ & $2.02 \%$ & $100 \%$ \\
\hline 7 & Working conditions & $0.00 \%$ & $100.00 \%$ & $0.00 \%$ & $100 \%$ \\
\hline 8 & Crèche facility & $6.63 \%$ & $88.76 \%$ & $4.61 \%$ & $100 \%$ \\
\hline
\end{tabular}

The information (Table 2) shows that moderate degree of mindfulness is most elevated in 'working-conditions'. The specialists know about the different plans dispatched by government. In any case, there is need for undeniable degree of mindfulness to abuse these plans and establish framework for better training and clinical offices for these laborers that will ease neediness and ad lib their day-to-day environments. Next let us see whether the degree of mindfulness is related with the age-gathering of laborers. The age was delegated 'under 20', '21-28', '29-36', '37-44', '45-52' and 'over 53' years. To dissect the consciousness of the respondents in the public authority plans identified with the beedi laborers dependent on their age, the accompanying invalid speculation was proposed.

HO: The beedi laborers don’t know about different advantages under the government assistance plans.

Kruskal-Wallis test was led to investigate the attention to the 347 respondents in the public authority's government assistance plans and their relationship to the beedi laborers' age. It tends to be derived from the above Table 3 that there lies a critical connection between the familiarity with government assistance plans and the age gathering of laborers as it is seen that for all factors the p-esteem is not exactly 0.05. In this manner, the invalid theory (HO) is dismissed at the 5\% degree of importance with respect to the above factors i.e., the beedi laborers don't know about different advantages under the government assistance plans. Along these lines, we acknowledge the substitute theory (H1) i.e., beedi laborers know about different advantages under the government assistance plans.

What's more, it very well may be examined that the determined worth of the Kruskal-Wallis test is lower than the basic chisquare incentive for all factors at 5 level of opportunity (i.e., 11.07), along these lines the invalid speculation that consolidates everything factors can be dismissed.

Likewise, it tends to be closed from the Table 3 that generally lower age bunch laborers between '21-28 years' and under ' 20 years' are more mindful about the government assistance plans than their higher age-bunch partner. The government assistance plans identified with health advantages, bunch protection, maternity benefits, working conditions and crèche offices are generally acknowledged and have mindfulness in the age gathering of '20-28 years', while lodging and training offices are common broadly among the age bunch 'under 20 years'. Notwithstanding, the amusement offices are broadly well known with the age-gathering of '37-44 years' of laborers. It is very fascinating that more youthful age of laborers is knowledgeable with the mindfulness plans than the more seasoned specialists (See table 3 ). 
Table 3: Awareness of Welfare Schemes and Age

\begin{tabular}{|c|c|c|c|c|c|c|c|c|c|}
\hline \multirow{2}{*}{ Welfare Schemes } & \multirow{2}{*}{$\begin{array}{l}\text { Chi-Square } \\
\left(\chi^{2}\right)\end{array}$} & \multirow{2}{*}{ Df } & \multirow{2}{*}{$\begin{array}{c}\mathbf{P} \\
\text { Value }\end{array}$} & \multicolumn{6}{|c|}{ Mean rank of Age-group } \\
\hline & & & & $<\mathbf{2 0}$ & $21-28$ & $29-36$ & $37-44$ & $45-52$ & $>53$ \\
\hline Medical & 7.410 & 5 & 0.000 & 163.28 & 218.13 & 165.77 & 153.79 & 136.17 & 177.89 \\
\hline Group insurance & 6.349 & 5 & 0.004 & 201.07 & 201.32 & 143.06 & 188.22 & 140.95 & 168.27 \\
\hline Housing & 10.063 & 5 & 0.001 & 203.93 & 178.98 & 150.99 & 174.51 & 131.5 & 191.74 \\
\hline Recreation & 8.386 & 5 & 0.002 & 204.16 & 185.3 & 163.89 & 206.28 & 121.33 & 164.22 \\
\hline Maternity benefit & 8.893 & 5 & 0.001 & 179.09 & 185.11 & 176.6 & 175.36 & 136.93 & 177.14 \\
\hline Education facility & 6.755 & 5 & 0.024 & 206.86 & 178.93 & 161.51 & 147.15 & 169.13 & 174.74 \\
\hline Working conditions & 9.656 & 5 & 0.006 & 177.74 & 180.04 & 172.45 & 177.37 & 163.07 & 171.45 \\
\hline Crèche facility & 2.928 & 5 & 0.008 & 177.99 & 188.94 & 148.49 & 188.76 & 154.62 & 182.52 \\
\hline
\end{tabular}

\section{Conclusion and Discussion}

The flow research study manages the familiarity with government assistance plans dispatched by government for the government assistance of beedi laborers. The examination depends on reactions assembled from laborers utilizing in unregistered limited scope arrangements of beedi moving at homes. The examination manages the predicament of these laborers in regards to their everyday environments, underpayment or non-installment of wages, sporadic business, absence of clinical and wellbeing offices and so on To enable these specialists, the public authority has dispatched different plans and laws that may ensure their privileges. The examination is homogenous in nature and is illustrative of whole labor force occupied with beedi moving the nation over.

The investigation likewise cites different creators and their examinations that structure a reason for absence of consciousness of government assistance plans among these laborers. The execution of these government assistance plans is of negligible use until they are made mindful to the laborers. Past investigations recommend that the state of beedi laborers has deteriorated over the past numerous many years. It is obvious that these specialists are misused by mediators, insufficient federal retirement aide benefits gave to them and their families, absence of admittance to government projects and developing neediness and weakness of families associated with the calling. In this manner, enrollment of all beedi fabricating units is significant with the goal that the specialists are not abused (Arora et.al, 2020).

Beedi producing is the second biggest industry in India that gives work to a huge number of monetarily and socially in reverse individuals of India. Since the assembling of beedi depends on utilization of tobacco that has high substance of nicotine and other unsafe synthetics, the specialists utilized in its moving are presented to a few deadly sicknesses and ailments. It is borne out from the current investigation that the beedi laborers are reasonably mindful about the government assistance plans; consequently, forceful projects of these government assistance plans ought to be carried out by the public authority to expand the mindfulness. There is a desperate requirement for intercessions from public and private area to limit tobacco openness, make mindfulness and give clinical assistance with respect to the utilization of tobacco by beedi laborers. Government ought to likewise find ways to authorize and change laws relating to Beedi and Cigar laborers (state of business) Act 1966, Bonded Labor System (Abolition Act) 1976, Child Labor Act 1986, Beedi Workers Welfare Fund Act 1976, and the Beedi Welfare Cess Act 1976 to give better working and day to day environments of beedi laborers (Kumar and Bharati, 2010).

As referenced before in the investigation, the pay level of the beedi laborers is extremely low and insufficient to do the trick for a family. There ought to be appropriate execution of projects for destitution mitigation like the National Rural Employment Guarantee Act of Government of India. 
As is unmistakably borne out from the information in the current examination that schooling status of laborers of beedi industry is alarmingly low; in this way, steps ought to be taken to improve the degree of instruction among these specialists to improve their present day to day environments. Certain administration drives like Integrated Child Development Services plot and the Sarva Siksha Abhiyan projects ought to be executed in among the specialists and their families in spaces of beedi fabricating (Kumar and Bharati, 2010).

\section{Limitations and Future Research}

Since Beedi fabricating is to a great extent chaotic in nature that forms a few issues for the specialists to gather dependable and precise information. The serious issue was the assortment of information from these semi-educated laborers who were moved toward a few times before the exact subtleties could be filled-in the survey. Besides, these laborers were hesitant to share genuine information inferable from their relationship with the specialists and outsider merchants. These laborers were regularly cajoled to share insights regarding the genuine condition of government assistance offices given by the state or their bosses. The current examination digs into the mindfulness about government assistance plans among Beedi laborers in the Northern piece of India and investigates the degree of infiltration of plans and government assistance programs carried out and executed viably. This investigation is very helpful in future arranging of plans remembering the situation of these specialists who are occupied with sloppy area for ages. The public authority and non-Government associations should concentrate on expanding the attention to these plans so better execution is feasible for the upliftment of these laborers.

Further scientists can investigate the chance of considering the importance and infiltration of different government plans jump started as of late for discovering the state of these specialists occupied with disorderly area. The labor assets of India are its spine for financial achievement and easing of neediness is conceivable through offering better types of assistance and offices to labor.

\section{References}

* (Author) Ph.D. Scholar- JSBS\&C, SHUATS-Prayagraj.

** (Co-Author), Assistant Professor, JSBS\&C, SHUATS-Prayagraj.

${ }^{1}$ Kumar Nakkeeran, S., \& Bharathi, S. (2010), A study on occupational health hazards among women beedi rollers in Tamilnadu, India. International Journal of Current Research, 11(1), 117-122.

${ }^{2}$ Arora, M., Datta, P., Barman, A., Sinha, P., Munish, V.G., Bahl, D., ... \& Tullu, F. (2020), The Indian Bidi Industry: Trends in Employment and Wage Differentials, Frontiers in Public Health.

${ }^{3}$ Ansari, M. S., \& Raj, A. (2015), Socio-Economic Status of Women Beedi Workers in Bundelkhand Region of Uttar Pradesh: An Empirical Analysis. UTMS Journal of Economics, University of Tourism and Management, Skopje, Macedonia, 6(1), 53-66.

${ }^{4}$ Ansari, M.S., \& Raj, A. (2020), A Study on Work Conditions of Home-Based Women Workers in India: Evidence from Beedi Industry, Mukt Shabd Journal, 9(9), 565-586.

${ }^{5}$ Sudina, M., \& Francis, L. A. J. (2015), Occupational health problems among beedi workers of Udupi district In South India. i-Manager's Journal on Nursing, 5(1), 24.

${ }^{6}$ Sudina, M., \& Lakra, A. J. (2015), Awareness on health and social welfare benefits among beedi workers-a community survey, Manipal Journal of Nursing and Health Sciences (MJNHS), 1(2), 100-103.

${ }^{7}$ Sundaramoorthy, R., Srinivasan, V., Gujar, J., Sen, A., Sekar, N., \& Abilash, V. G. (2013), Clinical, cytogenetic and CYP1A1 exon-1 gene mutation analysis of Beedi workers in Vellore region, Tamil Nadu, Asian Pacific Journal of Cancer Prevention, 14(12), 7555-7560.

8 Pankaj \& V. Dolas (2010), A Study of Socio-Economic Conditions among Bidi Workers in Solapur, Ugc Minor Research Project, File No.23-1374/09 (WRO), 24th February 2010.

${ }^{9}$ Devi, P., \& Thayammal, I. P. R. (2017), Aawareness of women beedi workers on government schemes related to the beedi workers. International Journal of Management Research and Reviews, 7(5), 559.

$* * * * * * * * * * * * * * * * * * * * * * * * * * * * * * * *$ 